DOSSIÊ TEMÁTICO: Política de Educação Superior

dO1 https://doi.org/10.22481/praxisedu.v16i41.7243

\title{
DÍVIDA PÚBLICA E FINANCIAMENTO DAS UNIVERSIDADES FEDERAIS E DA CIÊNCIA E TECNOLOGIA NO BRASIL (2003-2020)
}

\author{
PUBLIC DEBT AND FINANCING OF FEDERAL UNIVERSITIES AND SCIENCE AND \\ TECHNOLOGY IN BRAZIL (2003-2020)
}

\section{DEUDA PÚBLICA Y FINANCIACIÓN DE LA UNIVERSIDADES NACIONALES Y \\ CIENCIA Y TECNOLOGÍA EN BRASIL (2003-2020)}

\author{
Luiz Fernando Reis \\ Universidade Estadual do Oeste do Paraná - Brasil \\ Epitácio Macário \\ Universidade Estadual do Ceará - Brasil
}

\begin{abstract}
Resumo: $\mathrm{O}$ artigo analisa as despesas da União com a dívida pública, as universidades federais e a Ciência e Tecnologia (C\&T) no período de 2003 a 2020. Para o período de 2003 a 2019, foram examinadas as despesas liquidadas (orçamento executado). Para o ano de 2020, recorreu-se aos valores da dotação inicial da Lei Orçamentária Anual, sancionada em 17 de janeiro de 2020. Tais informações foram coletadas no portal da Câmara do Deputados, com exceção do ano de 2019, cuja fonte da coleta de dados foi o Sistema Integrado de Orçamento e Planejamento (SIOP). Os valores de todos os anos estão ajustados monetariamente para janeiro de 2020, com base no IPCA. A análise demonstra que, no período de 2003 a 2019, do total das despesas liquidadas pela União, $18,88 \%$, em média, se destinaram ao pagamento da amortização, juros e encargos da dívida pública. Nesse mesmo período, a função ciência e tecnologia $(\mathrm{C} \& \mathrm{~T})$ e as universidades federais receberam, respectivamente, $0,34 \%$ e $1,62 \%$ do total de despesas orçamentárias. A LOA/2020 prevê um aumento dos gastos com juros e encargos da dívida de 40,49\%, em relação ao orçamento executado em 2019. No caso das universidades, a previsão para 2020 é $0,58 \%$ inferior ao orçamento executado em 2019. A análise conclui que há inequívoca continuidade do padrão de acumulação rentista que resulta na crise de subfinanciamento das universidades e da C\&T. O enfrentamento consequente de tal crise se inscreve nas lutas mais gerais da sociedade contra a agenda regressiva em curso e por mudanças no referido modelo de acumulação.
\end{abstract}

Palavras chave: Dívida Pública; Financiamento da Educação Superior; Financiamento da Ciência e Tecnologia.

Abstract: This article analyzes Union's expenses with public debt, federal universities and Ciência e Tecnologia (C\&T) (Science and Technology) between 2003 and 2020 years. It was analyzed, between 2003 and 2009 years, the net expenses (executed budget). For the 2020 years, it was resorted to the initial allocation's values from Lei Orçamentária Anual (Anual Budget Law), sanctioned on 2020, the 17th of January. Such informations was collected on House of Representatives' site, except the 2019 
years, which data collection's source was from Sistema Integrado de Orçamento e Planejamento (SIOP) (Planning and Budget's Integrated System). The values of every year are ajusted monetarily for 2020, January, based on IPCA. The analyze shows that, between 2003 and 2019, from Union's total net expenses, $18,88 \%$ on average, were destinated to amortization, interest and charges' payment from public debt. Meanwhile, the Science and Technology (C\&T) function and federals universities received, respectively, $0,34 \%$ and $1,62 \%$ from total of budget's expenses. LOA/2020 predicts a increase spending with debt's charges and interest of $40,49 \%$ in relation to the budged executed in 2019. In case of universities, the predict to 2020 is $0,58 \%$ lower than 2019 's executed budget. The analyzes concludes that there is unmistakably continuity of rentist accumulation pattern that results on universities and C\&T's underfunding crisis. The consequent facing of such crisis is inscribed on society's more general struggles against the ongoing regressive planning and for changes in said accumulation's model.

Keywords: Public Debt; Financing of Higher Education; Financing of Science and Technology.

Resumen: El artículo analiza los gastos del Gobierno Nacional en deuda pública, universidades nacionales y Ciencia y Tecnología (C\&T) en el período de 2003 a 2020. Para el período de 2003 a 2019, se examinaron los gastos liquidados (presupuesto ejecutado). Para el año 2020, utilizamos los valores de la asignación inicial de la Ley de Presupuesto Anual, sancionada el 17 de enero de 2020. Dicha información se recopiló en el portal de la Cámara de Diputados, con la excepción de 2019, cuya fuente de recopilación de datos fue el Sistema Integrado de Presupuesto y Planificación (SIOP). Los valores para todos los años se ajustan monetariamente para enero de 2020, según el IPCA. El análisis muestra que, en el período comprendido entre 2003 y 2019, de los gastos totales liquidados por el Gobierno Nacional, el $18.88 \%$, en promedio, se utilizó para pagar la amortización, los intereses y los cargos de la deuda pública. En el mismo período, la función de ciencia y tecnología (C\&T) y las universidades nacionales recibieron, respectivamente, el $0,34 \%$ y el $1,62 \%$ de los gastos presupuestarios totales. El LOA / 2020 pronostica un aumento en el gasto en intereses y cargos de deuda del 40.49\%, en comparación con el presupuesto ejecutado en 2019. En el caso de las universidades, el pronóstico para 2020 es $0.58 \%$ menor que el presupuesto ejecutado en 2019 . El análisis concluye que existe una continuidad inequívoca del patrón de acumulación rentista que resulta en la crisis de financiación insuficiente de las universidades y C\&T. El consecuente manejo de tal crisis es parte de las luchas más generales de la sociedad contra la agenda regresiva en curso y por los cambios en el modelo de acumulación mencionado anteriormente.

Palabras clave: Deuda pública; Financiación de la Educación superior; Financiación de la Ciencia y la Tecnología.

\section{Introdução}

O texto analisa o financiamento das universidades federais e da ciência e tecnologia no período de 2003 a 2020. Estes dados são cotejados com o montante de recursos destinado, ano a ano, para o pagamento da dívida pública brasileira. A análise comparativa é importante, na medida em que, segundo se compreende, a dívida pública representa um obstáculo estrutural à destinação de receitas da União à altura das necessidades de custeio das políticas sociais, educação e ciência e tecnologia. 
O artigo tem como centro a análise das despesas da União com a dívida pública, com as universidades federais (inclusive hospitais universitários), a função ciência e tecnologia (C\&T), o Conselho Nacional de Desenvolvimento Científico e Tecnológico (CNPq) e com a Coordenação de Aperfeiçoamento de Pessoal de Nível Superior (CAPES), no período de 2003 a 2020. Para o período de 2003 a 2019, foram analisadas as despesas liquidadas (orçamento executado). Relativamente a 2020, recorreu-se aos valores da Dotação Inicial ${ }^{1}$ da Lei Orçamentária Anual $^{2}$, sancionada em 17 de janeiro de 2020 pelo presidente Bolsonaro. As informações foram coletadas no portal da Câmara Federal (2020), com exceção do ano de 2019, cuja fonte da coleta de dados foi o Sistema Integrado de Orçamento e Planejamento (SIOP, $2020^{3}$ ). Os valores de todos os anos estão ajustados monetariamente para janeiro de 2020, com base no Índice de Preços ao Consumidor Amplo (IPCA/IBGE).

\section{Enquadramento do problema}

A política de ensino superior e de ciência e tecnologia (C\&T) expressa, ao mesmo tempo, um diagnóstico da situação econômica, política e social do País e a orientação ou o rumo da mudança que se pretende imprimir nessa realidade. Constitui, pois, uma porta privilegiada de análise das diretrizes políticas que orientam o modelo econômico, haja vista a importância do conhecimento técnico e científico para a produção e valorização do valor nos circuitos produtivos mundiais. Eis por que as iniciativas do Estado relativas à estruturação e fomento de complexos produtores de conhecimentos tendem a se ligar à produção econômica, subordinando-se ao jogo de forças de interesses que comandam a produção e distribuição de mercadorias em escala nacional e mundial. Tais jogos de forças e interesses se expressam na política econômica em curso em determinado país num período, mais ou menos extenso.

No caso brasileiro, desde o Governo de Fernando Collor de Mello e, fundamentalmente, o de Fernando Henrique Cardoso, a política econômica se traduz numa série de medidas para atender os interesses do capital rentista, ao tratar como prioridade

\footnotetext{
${ }^{1}$ Refere-se ao valor inicial constante da Lei Orçamentária Anual. Publicada a Lei Orçamentária Anual (LOA), pode-se verificar a necessidade de ajustar a programação. Durante o ano, o valor inicial poderá ser acrescido via crédito suplementar, por exemplo, ou reduzido, por meio de contingenciamento de recursos, que consiste no retardamento ou, ainda, na inexecução de parte da programação de despesa prevista na Lei Orçamentária. Assim, o Governo Federal emite um decreto limitando os valores autorizados na LOA.

${ }^{2}$ Lei $\mathrm{n}^{\circ} 13.978$, de 17 de janeiro de 2020, estima a receita e fixa a despesa da União para o exercício financeiro de 2020 .

${ }^{3}$ O SIOP apresentava, na época da consulta, valores da execução orçamentária até 7 de fevereiro de 2020. A Câmara dos Deputados oferecia valores da execução orçamentária até 31 de dezembro de 2019. Por esta razão, para o ano de 2019, optou-se pelas informações mais atualizadas disponibilizadas pelo SIOP.
} 
absoluta a destinação de recursos do orçamento da União para o pagamento da dívida pública. Por esta via, o Estado brasileiro atua diretamente na valorização do capital rentista, transformando o País, como demonstra Leda Paulani (2008), numa plataforma de valorização das finanças mundializadas. Este é um dos traços característicos do padrão de acumulação de capital instaurado com o fim da ditadura civil-militar, instaurada em 1964. Padrão este que se desdobra ora com menor ou maior atuação do Estado nos negócios, ora com maior ou menor esforço de promoção de políticas compensatórias. O maior ou menor grau de participação do Estado nos negócios e na promoção de políticas sociais constitui um dos elementos definidores das diferenças entre a primeira fase do neoliberalismo brasileiro (final dos anos 1980 a 2002), a segunda fase (que compreende os governos petistas, marcadamente o período que vai de 2006 a 2013) e a terceira assinalada pela emergência do ultraliberalismo sob comando de um governo de extrema direita (fase que deu os primeiros sinais em 2014, mas se impôs com o impeachment da ex-Presidente Dilma Rousseff, em 2016). ${ }^{4}$

Sem descuidar das inflexões operadas desde o segundo mandato de Lula da Silva (2007), evidenciadas por vários analistas, é importante compreender que as diferenças na política econômica e no manejo dos orçamentos em prol do fortalecimento de programas e políticas sociais se deram sobre a base da continuidade dos parâmetros neoliberais. ${ }^{5} \mathrm{O}$ mesmo se aplica à intervenção dos governos petistas na seara do ensino superior e da C\&T - objeto deste estudo.

No plano econômico, segundo acertada crítica de Plínio de Arruda Sampaio Jr. (2012, p. 679),

O desafio do neodesenvolvimentismo consiste, portanto, em conciliar os aspectos "positivos" do neoliberalismo - compromisso incondicional com a estabilidade da moeda, austeridade fiscal, busca de competitividade

\footnotetext{
4 Tratando da realidade sul-americana, Maristela Svampa sugere outra temporalidade e caracterização. Em seu livro Del cambio de época al fin de ciclo, a autora defende o argumento de que a solda do neoliberalismo nos anos 1990 fora dada pelo Consenso de Washington cuja base está no capital financeiro. Desde os 2000, instaurou-se o Consenso das Commodities que se baseia no neoextrativismo. No último caso, o padrão de acumulação neoextrativista foi incorporado por governos de variadas orientações ideológicas e políticas, com destaque para os progressistas que viram nas "vantagens comparativas" da produção e exportação de bens primários a chance de emplacar seu modelo neodesenvolvimentista. "En la visión progresista, el Consenso de los commodities aparece associado a la acción del Estado como productor y regulador, así como a uma batería de políticas sociales, dirigidas a los sectores más vulnerables, cuya base misma es la renta extraordinaria asociada al modelo extractivo-exportador". (SVAMPA, 2017, P. 57).

5 Cf. Carcanholo (2018), para quem “[...] o neoliberalismo não se define por um a política econômica ortodoxa”, mas, "segundo seus defensores", primeiramente "pela estabilização macroeconômica como pré-requisito fundamental" e, na sequência, pela realização das "reformas estruturais liberalizantes (privatizações, liberalização e abertura dos principais mercados)." Isso resultaria, segundo o autor, no aprofundamento dos mecanismos de transferência de valor das periferias para os centros dinâmicos do capitalismo, reforçando a dependência estrutural. A política de C\&T praticada pelos governos progressistas se enquadram perfeitamente nessa concepção.
} 
internacional, ausência de qualquer tipo de discriminação contra o capital internacional - com os aspectos "positivos" do velho desenvolvimentismo - comprometimento com o crescimento econômico, industrialização, papel regulador do Estado, sensibilidade social.

A mesma conduta tateante que, no projeto econômico, renega o que houve de mais consequente no nacional-desenvolvimentismo e incorpora elementos fundamentais do neoliberalismo, é expressa na formulação da política de C\&T e de ensino superior. Com efeito, essas políticas deveriam atender a interesses díspares de setores sociais diversos e até antagônicos, o que responde à clássica fórmula do "pacto de classe" operado por Lula da Silva, como chamou com todas as letras o economista Bresser-Pereira. Uma política colaboracionista amplamente fundada no manejo do erário, com largos benefícios para as frações empresariais diretamente interessadas em explorar a seara da C\&T e do ensino superior.

Sob a justificativa de aumentar a capacidade técnica das empresas e, por este meio, potencializar a competitividade da economia doméstica ante a concorrência internacional, governo e legisladores não pouparam esforços para destroçar as normas constitucionais e infraconstitucionais que protegiam o mercado interno, as empresas estatais e nacionais e a produção de ciência básica, com vistas a diminuir a distância técnico-científica do País em relação às nações de capitalismo central. Ao mesmo tempo em que se adequavam os aparatos normativos das universidades (LIMA, 2007; 2009), de empresas e institutos públicos de pesquisa à demanda do mercado, de conformidade com a ideologia da inovação, o governo de colaboração de classe era instado a responder a demandas contingenciais de setores sociais progressistas e de esquerda, das comunidades científicas e acadêmicas. $\mathrm{O}$ aceno positivo para sua base social se deu dentro dos marcos neoliberais num contexto externo favorável ${ }^{6}$ e de aumento da arrecadação, materializando-se na destinação de fundos estatais para políticas de transferência de renda e de combate à pobreza, por exemplo. Já as comunidades acadêmicas e de pesquisadores foram privilegiadas com aumento de verbas para as instituições de ensino superior e para as agências de fomento à pesquisa, lastreadas na política de editais que favoreciam amplamente a figura do empreendedor acadêmico.

\footnotetext{
${ }^{6}$ Dois fatores concorreram para o contexto externo favorável: o crescimento da demanda e a alta nos preços das principais commodities exportadas pelo Brasil. Em artigo irretorquível sobre a crise do governo Dilma Rousseff, Perry Anderson (2016) informa: "No final do segundo mandato de Lula, a fatia correspondente da exportação de bens primários dentre as exportações brasileiras subiu de 28 para $41 \%$, no que o espaço dos bens manufaturados caiu de 55 para 44\%; no final do primeiro mandato de Dilma, as matérias-primas eram responsáveis por mais da metade do valor das exportações. Mas de 2011 em diante, os preços das principais mercadorias comercializadas pelo país entraram em colapso: o minério de ferro caiu de 180 dólares para 55 dólares a tonelada, a soja caiu de aproximadamente 40 dólares a saca para 18 dólares, o petróleo cru despencou de 140 dólares para 50 dólares o barril. E reagindo ao fim da bonança do comércio exterior, o consumo doméstico também entrou em declínio".
} 
Em parte, o incremento orçamentário destinava-se ao atendimento de reivindicações pontuais da sociedade brasileira, como a expansão das universidades e institutos federais, bolsas e auxílios para pesquisadores e estudantes, bem como Política Nacional de Assistência Estudantil (PNAES). De outra parte, o governo abria os mananciais do fundo público para a iniciativa privada mediante programas como o Financiamento Estudantil (FIES) e o Programa Universidade para Todos (ProUni), subsidiando o investimento e a acumulação nessa senda e catapultando a concentração de capitais nas mãos de três ou quatro grupos empresariais com uma cotação na bolsa de valores acima de empresas como Petrobras e Vale. ${ }^{7}$

Neste particular, a política de ensino superior e de C\&T imitava o que se fazia no plano econômico com as empresas "campeãs nacionais", que encheram as burras de dinheiro do BNDES, concentraram poder e capital, internacionalizaram-se e investiram parte dos recursos e incentivos recebidos no sistema financeiro. ${ }^{8}$ A similaridade com a política econômica é plasticamente sensível, também, na ideologia que orientou os marcos regulatórios da $\mathrm{C} \& \mathrm{~T}$ no ciclo progressista brasileiro: um amálgama das ideias de desenvolvimentismo de novo tipo, inovação e empreendedorismo. Com efeito, o complexo de instituições públicas direcionado à produção de conhecimento científico e tecnológico fora instado a vincular sua agenda de pesquisa e suas estruturas às demandas do mercado - diga-se em bom e claro português, às exigências das empresas. Os influxos dessa orientação ainda serão sentidos nas instituições de ensino superior, empresas e institutos públicos de pesquisa e podem ser devastadores para a estrutura institucional, ainda mais se a correlação de forças permitir a implementação do programa do Ministério da Educação, Future-se - que, se entende - é um arremate nos traços regressivos e antinacionais presentes nos marcos regulatórios de C\&T urdidos no período dos governos petistas.

\footnotetext{
${ }^{7}$ A respeito da mercadização da educação superior em mãos dos oligopólios educacionais, ver a seminal pesquisa de Valdemar Sguissardi Estudo diagnóstico da política de expansão da (e acesso à) educação superior no Brasil de 2002-2012, no âmbito do edital número 51/2014 - SESU-MEC. Além de fazer incontornável síntese da evolução do ensino superior e fornecer amplo exame de bibliografia nacional e internacional sobre o assunto, o autor demonstra como os fundos estatais foram fundamentais para alavancar o crescimento e a concentração de capital nesse nicho de mercado.

${ }^{8}$ Este aspecto é tratado na análise panorâmica intitulada Uma história da onda progressista sul-americana (1998-2016), de Fábio Luis Barbosa dos Santos. Na obra, o professor da Unifesp analisa criticamente a política de integração sul-americana protagonizada pelos governos petistas, bem como o fomento das empresas "campeãs nacionais" sobre as quais afirma: "[...] empresas beneficiadas por vultosos aportes do banco [BNDES], mas que, pouco depois, passaram para o controle internacional; operações que receberam apoio para se internacionalizarem e se autonomizaram, pouco colaborando para a exportação de serviços e produtos brasileiros; e, por fim, evidências de que 'campeãs nacionais' aplicaram em especulação financeira empréstimos subsidiados, destinados a estimular a exportação de bens e serviços”. (2018, p. 312).
} 


\section{Sistema tributário e dívida pública: óbices ao financiamento de políticas sociais}

A ideia de que as políticas sociais constituem a única ou a principal via de realização de mudanças sociais baseia-se em premissas falsas. Por um lado, descura a formação e alocação do fundo público de seu conteúdo econômico, deslocando-a para a esfera estrita das disputas em torno dos orçamentos e trata as rendas que constituem o referido fundo como algo abstrato, não determinado e ilimitado. De outra parte, pressupõe uma fantástica disposição do Estado de promover justiça social, sobre a base de amplo espectro de direitos (trabalhistas e sociais), se as forças políticas progressistas atuarem nessa direção. Geralmente tomam por espelho as experiências de Welfare State, muitas vezes sem atentar para as circunstâncias históricas que as urdiram em poucos países situados no topo da divisão internacional do trabalho e nos paraísos fiscais - experimentos que, hoje, estão em franco processo de desmonte em vários Estados. Quem assim pensa descuida também das particularidades que regem as economias dependentes, a complexidade e heterogeneidade do mundo do trabalho e do tecido social destas sociedades.

Os estudos que têm por base a Crítica da Economia Política mostram, todavia, que tanto a formação quanto a alocação do fundo público são transpassadas, de fato, pela luta entre as classes fundamentais e suas frações internas. Com efeito, o sistema tributário do País, tanto quanto as prioridades na alocação dos orçamentos estatais, é objeto das mesmas determinações do padrão de acumulação de capital e dos enfrentamentos que se desdobram entre as classes pela apropriação dos excedentes econômicos e, dentro destes, o fundo público. ${ }^{9}$ Num padrão rentístico de acumulação - que no Brasil impõe as regras da política econômica desde os anos de 1990 - não é de se admirar que as margens de manobra para a promoção de políticas sociais sejam tão diminutas, porquanto o próprio sistema tributário e o da dívida pública são montados para proteger o patrimônio, a propriedade e as altas rendas do capital financeiro e fictício. ${ }^{10}$ Os dados expressos a seguir se prestam a ilustrar o que aqui se afirma.

\footnotetext{
9 Abordagem seminal foi feita por Francisco de Oliveira (1998) que teorizou sobre o fundo público como antivalor. O estudo do professor Evilásio Salvador (2010) constitui leitura obrigatória nessa direção crítica.

${ }^{10}$ De acordo com Guttmann (2008), Marx estabeleceu uma distinção entre o capital de empréstimo (capital portador de juros), que se amplia com uma parte do lucro obtido pelo capital produtivo, e o capital fictício cuja valorização se dá em razão de expectativas futuras, da capitalização do rendimento antecipado sem qualquer contrapartida direta em capital produtivo. Para Reis (2015), o capital fictício, conceito proposto por Marx, diz respeito à multiplicação ilusória da riqueza real por intermédio de mecanismos monetários e financeiros. Marx identificou como principais fontes do capital fictício as ações negociadas nas bolsas de valores, os títulos da dívida pública e a moeda de crédito, emitida pelos bancos sem lastro em depósitos respectivos. Além das modalidades enunciadas por Marx, o capital fictício, atualmente, assumiu o formato de outros títulos
} 
A prioridade conferida ao pagamento da dívida pública pela política econômica, em curso no Brasil desde os anos de 1990, resulta, dentre outras consequências, na ampliação da carga tributária e na restrição dos recursos destinados ao financiamento das políticas sociais, da educação superior e da ciência e tecnologia.

A carga tributária no Brasil apresenta um crescimento constante. De 1988 a 2017, cresceu 38\%. Em 1988, a carga tributária arrecadada pelos entes federados representava 23,4\% do Produto Interno Bruto (PIB) e em 2017 passou a ser de 32,3\% (SENADO FEDERAL, 2018). O aumento da carga tributária tem sido ardilosamente utilizado por formuladores de política econômica como apelo para rebaixar a tributação, elegendo esta como a principal vilã do baixo dinamismo da economia. Essa narrativa tem por objetivo desonerar o investimento de capitais e patrimônio, o que tem influxo negativo sobre o fundo público, restringindo a margem de manobra do Estado na promoção de políticas sociais. Com base em pesquisa de especialistas no assunto, Reis e Macário (2018, p. 128) se pronunciaram sobre o gigantismo da carga tributária brasileira como narrativa ideológica:

Tal ideologia esconde, por exemplo, o fato de que a sociedade brasileira se estrutura sobre a base de uma profunda desigualdade, cujo equacionamento se não é possível nos marcos da nossa formação social, tampouco pode ser mitigada sem o concurso de políticas públicas universais. Estas políticas não tem como se efetivar sem os fundos estatais correspondentes, razão porque o cavalo de batalha contra a tributação contrasta com as pretensões de promoção de direitos de cidadania. A gritaria sobre a carga tributária serve, ainda, para enublar a óptica da população sobre seu inequívoco caráter de Robin Hood às avessas: um mecanismo que subtrai parte substantiva dos rendimentos dos que vivem do seu trabalho em favor da proteção dos lucros, das altas rendas e do patrimônio dos que dominam econômica e politicamente a sociedade brasileira.

Em importante estudo, a professora Tathiane Brettas (2012) apoia-se em pesquisa do IPEA (Instituto de Política Econômica Aplicada) para afirmar que, no Brasil, famílias com renda mensal de até dois salários mínimos gastam em média 50\% desse valor com pagamento de tributos, ao passo que aqueles com renda de mais de 30 salários mínimos pagam menos de $30 \%$. Por seu turno, a Secretaria da Receita Federal (2017 ${ }^{11}$ ) informa que 73,7\% do total da carga tributária incide sobre o trabalho e o consumo, enquanto a tributação da propriedade e das transações financeiras não ultrapassa 6,7\%. Complemente-se o quadro com as seguintes

negociáveis, especialmente os chamados derivativos de créditos que se expandiram de maneira extraordinária com a formação de um mercado internacionalizado de obrigações, desde os anos 1980.

${ }^{11}$ Estudo mais recente sobre a carga tributária no Brasil. A Secretaria da Receita Federal tem publicado, ininterruptamente, tais estudos desde 1995. O estudo referente à carga tributária do ano de 2018 deveria ter sido publicado em novembro de 2019. Até agora, contudo, ele não foi divulgado. A Secretaria da Receita Federal também não informou o motivo da não publicação da pesquisa. 
informações: o Imposto Sobre Grandes Fortunas, previsto na Constituição de 1988, até hoje não foi implantado; acionistas de grandes empresas e bancos não pagam impostos sobre dividendos; e proprietários de aeronaves (jatinhos e helicópteros) e embarcações (iates) não pagam IPVA (Imposto sobre a Propriedade de Veículos Automotores).

Esses dados já indicam a possibilidade de ampliação dos recursos do fundo público para o financiamento de políticas mitigadoras das graves expressões da questão social que assolam o País. Para tanto, é incontornável a realização de uma reforma tributária que supere a natureza regressiva da atual, tributando intensa e progressivamente as grandes riquezas, o patrimônio e a renda dos ricos, ao passo que desonere o consumo e os estratos mais pobres da população. ${ }^{12}$ Como se vê, isto configura uma reforma que remexe interesses incrustados na estrutura social e econômica do País, implicando o sistema de propriedade do capital, a estrutura patrimonial sobradamente concentradora da riqueza e a renda do Brasil.

Também neste particular, pela ausência de qualquer iniciativa reformadora e via anuência aos interesses econômicos que se alimentam da regressividade tributária, os governos petistas representaram inequívoca continuidade (2003-2016), com nova roupagem, do neoliberalismo dos anos 1990.

Esta continuidade se patenteou, ainda mais, na manutenção e fortalecimento do sistema da dívida pública, responsável por drenar parcelas imensas do erário para pagamento de seus custos. A análise do montante de recursos destinados ao pagamento de juros e encargos, amortização e refinanciamento da referida dívida é, por si mesma, suficiente para comprovar essa afirmação. As obrigações, que se multiplicam por si, também estão na raiz da política de "austericídio" que marcou os anos 1990, o primeiro governo Lula da Silva, o segundo mandato de Dilma Rousseff e os governos pós-golpe de $2016^{13}$. Os sucessivos cortes

\footnotetext{
${ }^{12}$ Em decorrência dos protestos populares no Chile, iniciados no fim de 2019, o governo Piñera, pressionado a ampliar os recursos destinados às políticas sociais, propôs uma reforma tributária. Tal proposta, aprovada posteriormente pelo Parlamento no final de janeiro/2020, busca aumentar a arrecadação anual de impostos em R \$ 9,307 bilhões, 55\% dos quais virão exclusivamente de impostos aplicáveis aos mais ricos. A nova legislação deverá entrar em vigor em março e estabelece ainda a redução dos impostos para idosos e um imposto sobre serviços digitais, como a Netflix e o Spotify. O projeto também simplifica a cobrança de impostos corporativos, estabelecendo uma taxa de 27\% para as grandes empresas (CHILE..., 2020). De acordo com Gombata (2020), dentre os pontos mais importantes da reforma tributária chilena estão elevação da alíquota de imposto de renda de $35 \%$ para $40 \%$ para quem ganha acima de US $\$ 20$ mil e a criação de sobretaxa sobre patrimônio imobiliário de mais de US\$532.127.

${ }^{13}$ Recorremos aqui à caracterização do impeachment de Dilma Rousseff como um golpe de novo tipo que se realiza, na boa síntese de Mascaro $(2018$, p. 87), "sem precisar no mais das vezes recorrer aos Exércitos, o controle da opinião social conduz a impeachments, que, por sua vez, levam a choques neoliberais extremados, com quebras de direitos sociais a privatizações a custo baixíssimo". Tratou-se, pois, de um golpe de reacomodação das frações burguesas em face das exigências postas pela crise do capital, em 2008, reclamando reordenamentos no padrão de acumulação de capital vigente na América Latina, por exemplo. A implementação da agenda regressiva empalmada pelo capital internacional que opera no Brasil em imbricação com capitais locais certamente encontraria obstáculos no governo de Dilma Rousseff, embora tenha se iniciado sob a batuta
} 
de verbas para políticas sociais, a EC 95/16 (teto dos gastos públicos), a Reforma Trabalhista e a privatização de grandes e rentáveis empresas estatais se ligam diretamente ao imperativo imposto pelos bancos e fundos de pensão, detentores dos títulos da dívida pública. São, pois, medidas que subordinam a política econômica do País ao imperativo do ajuste físcal para gerar excedentes suficientes que garantam o pagamento do serviço ${ }^{14}$ (juros, encargos e amortizações) da dívida pública.

Outra consequência da prioridade absoluta conferida pela política econômica ao pagamento da dívida pública é a restrição dos recursos destinados ao financiamento das políticas sociais. Análise minuciosa do montante de recursos destinado ao pagamento de juros, amortizações e refinanciamento da dívida pública é por si suficiente para comprovar essa afirmação. A política econômica beneficia, especialmente, o capital rentista em detrimento da população que carece da proteção social do Estado. Eis a chave explicativa para a implementação de uma agenda regressiva que resulta na aprovação das contrarreformas: a Emenda Constitucional 95/2016 e as chamadas Reforma Trabalhista e da Previdência.

Sabe-se que as outras contrarreformas estão em curso para ampliar a destinação de recursos do fundo público a fim de garantir, especialmente, a rentabilidade do capital rentista, como é o caso da PEC (Proposta de Emenda à Constituição) no 186/2019, que dispõe sobre medidas permanentes e emergenciais de controle do crescimento das despesas obrigatórias e de reequilíbrio fiscal no âmbito dos Orçamentos Fiscal e da Seguridade Social da União, e dá outras providências.

Mesmo durante os governos do Partido dos Trabalhadores, com a adoção de uma agenda social que procurava compatibilizar os interesses do capital e do trabalho, a sangria de recursos do fundo público para os detentores dos títulos da dívida pública manteve-se intocada. Como efeito, no período de 2003 a 2019, foram destinados, cumulativamente, R\$

da presidente reeleita em 2014. Abrangência, profundidade, velocidade e forma política de implementação não poderiam, porém, ser atendidas a contento por um governo do Partido dos Trabalhadores. A destituição da mandatária e a reacomodação de todo o staff governamental, até o terceiro escalão, apresentava-se, portanto, como necessidade histórica para as frações do capital mais diretamente integradas ao rentismo e ao capital internacional. O golpe se deu, pois, dentro da institucionalidade porque desencadeado no poder legislativo, autorizado e codirigido pelo judiciário, forjado amplamente pelos meios de comunicação de massa - mesmo que o motivo alegado, as chamadas pedaladas fiscais, não oferecesse qualquer base jurídica, segundo argumento do aclamado professor de Filosofia do Direito. A agenda regressiva imposta pós-golpe é já de amplo conhecimento público: desmonte de direitos trabalhistas e sociais, congelamento dos gastos primários do Estado, rebaixamento das condições morais e econômicas de reprodução da força de trabalho, privatização e desnacionalização crescentes, realinhamento com a política estadunidense e constante tensionamento da institucionalidade com militarização do governo e das instituições sociais. Foi golpe!

${ }^{14}$ Não inclui o refinanciamento (rolagem) da dívida pública que se dá por meio da emissão de títulos públicos federais. 
20,095 trilhões ${ }^{15}$ para o pagamento de juros, amortizações e refinanciamento ("rolagem") da dívida pública, os quais representaram, em média, 45,66\% do orçamento da União e 19,45\% do Produto Interno Bruto (PIB). Considerados apenas juros, encargos e amortizações, a União pagou nada menos do que $\mathrm{R} \$ 8,431$ trilhões no período, cifra que assegurou a valorização do capital na esfera financeira. Isto significou que, nos 17 anos analisados, o governo federal destinou, em média, 18,88\% do orçamento da União, o equivalente a 7,89\% do PIB, somente para o pagamento de juros, encargos e amortizações da dívida pública.

O total de recursos destinados cumulativamente, no período de 2003 a 2019, somente ao pagamento de juros, encargos e amortizações da dívida pública (R\$ 8,431 trilhões), representou 11 vezes mais do que os recursos destinados às universidades ( $\mathrm{R} \$ 7333,868$ bilhões) e 54 vezes mais que os recursos recebidos pela área de ciência e tecnologia (R\$ 155,823 bilhões).

Nesse particular, o governo de extrema direita de Jair Bolsonaro representa a continuidade da lógica do padrão de acumulação rentístico, vigente desde os anos de 1990, inovando apenas quanto aos instrumentos legais que espoliam a renda dos trabalhadores e do povo em favor do capital financeiro. Assim, o projeto de LOA/2020 previu um aumento das despesas com juros e encargos da dívida pública de 40,49\% em relação ao orçamento executado em 2019: de R \$ 291,538 bilhões (2019) para R \$ 409,567 (2020). Considerando-se as despesas totais com a dívida pública (juros e encargos, amortização e refinanciamento) haverá um crescimento de 51,05\% dessas despesas: de R\$1,061 trilhão, em 2019, para 1,603 trilhão em 2020.

Esses dados já permitem afirmar que, juntamente com o sistema tributário regressivo, o "sistema da dívida" constitui obstáculo estrutural à superação da crise de subfinanciamento das universidades e da ciência e tecnologia no Brasil.

O pagamento da dívida pública, sem a realização da auditoria preconizada pela Constituição Federal ${ }^{16}$, continua a exigir do Estado brasileiro a destinação crescente dos tributos arrecadados para o pagamento de amortização, juros e encargos a grandes bancos e instituições financeiras, nacionais e internacionais. A destinação prioritária dos recursos do

\footnotetext{
${ }^{15}$ Valores atualizados pelo IPCA (IBGE) para janeiro de 2020.

${ }^{16} \mathrm{O}$ artigo 26 do Ato das Disposições Constitucionais Transitórias (ADCT), da Constituição Federal de 1988, determinou que, "[...] no prazo de um ano a contar da promulgação da Constituição, o Congresso Nacional promoverá, através de Comissão mista, exame analítico e pericial [auditoria] dos atos e fatos geradores do endividamento externo brasileiro. [...] Apurada irregularidade, o Congresso Nacional proporá ao Poder Executivo a declaração de nulidade do ato e encaminhará o processo ao Ministério Público Federal, que formalizará, no prazo de sessenta dias, a ação cabível".
} 
fundo público para os rentistas resulta, dentre outras consequências, na restrição do financiamento das universidades federais e do complexo de ciência e tecnologia no Brasil.

\section{O financiamento das universidades federais e da ciência e tecnologia no Brasil (2003- 2020)}

Antes de apresentar os valores destinados no período de 2003 a 2019 (orçamento executado) e os recursos previstos para 2020, pela Lei Orçamentária Anual, para o financiamento das universidades federais e da ciência e tecnologia, é necessário tecer algumas considerações a respeito da Lei Orçamentária de 2020.

A despesa total fixada nos Orçamentos Fiscal e da Seguridade Social ${ }^{17}$ para o exercício financeiro de 2020 é de $\mathrm{R} \$ 3,566$ trilhões, incluindo $\mathrm{R} \$ 917,1$ bilhões para o refinanciamento da dívida pública federal (interna e externa). Cabe destacar, entretanto, que parte de tais recursos não está assegurada, estando na dependência de aprovação de créditos adicionais (emissão de títulos da dívida pública). Para tanto, será necessário "quebrar" a chamada Regra de Ouro da Constituição Federal (Art. 167, Inciso III ${ }^{18}$ ). É importante frisar que há estreita relação entre essa proposição na LOA/2020 e a PEC 186/2019, que dispõe sobre medidas permanentes e emergenciais de controle do crescimento das despesas obrigatórias, como nos casos dos dispêndios com pessoal, pagamento de aposentadorias e pensões e gastos com saúde e educação, constitucionalmente vinculados a uma parcela da receita da União.

De acordo com a Agência Senado (VOTAÇÃO..., 2019), o objetivo principal da PEC 186/2019 é a contenção do crescimento das despesas obrigatórias para todos os níveis de governo (federal, estadual, distrital e municipal), de maneira a viabilizar o gradual ajuste fiscal. Entre as medidas de ajuste, está a inclusão das despesas com pensionistas no limite dos gastos com pessoal. A PEC estabelece medidas de contenção de gastos quando o Congresso Nacional autorizar a quebra da, há pouco citada, Regra de Ouro. Nesse caso, a PEC determina medidas de ajuste que irão atingir os servidores públicos: suspensão de progressão na carreira, proibição de concursos, vedação a pagamento de certas vantagens e redução da jornada de trabalho com diminuição de salário (em até $25 \%$ ) são algumas dentre muitas outras medidas propostas.

\footnotetext{
${ }^{17}$ Não inclui R\$ 121, 4 bilhões do Orçamento de Investimento.

${ }^{18}$ Art. 167. São vedados: ... III - a realização de operações de créditos que excedam o montante das despesas de capital, ressalvadas as autorizadas mediante créditos suplementares ou especiais com finalidade precisa, aprovados pelo Poder Legislativo por maioria absoluta. (CONSTITUIÇÃO FEDERAL, 1988).
} 
A chamada Regra de Ouro busca evitar o uso de recursos provenientes da emissão de títulos da dívida pública federal para o pagamento de despesas correntes. De acordo com dita regra, o total de operações de crédito, emissão de títulos da dívida, não pode ser maior do que as despesas de capital ${ }^{19}$.

Para o orçamento de 2020, o governo federal propôs que parte das despesas correntes no montante de $\mathrm{R} \$ 343,6$ bilhões seja provida pela emissão de títulos da dívida pública. Essas despesas são consideradas condicionadas, pois superaram o total das despesas de capital, previstos na LOA/2020 em R $\$$ 1,388 trilhão. O governo federal previu a emissão de títulos da dívida pública num montante de $\mathrm{R}$ \$ 1,731 trilhão: $\mathrm{R}$ \$ 343,6 bilhões acima das despesas de capital. Conforme determina a Regra de Ouro, a emissão desses R \$ 343,6 bilhões depende da aprovação pela maioria absoluta dos membros do Congresso Nacional, nos termos do art. 167, inciso III, da Constituição. As despesas condicionadas se distribuem conforme o quadro 1.

Quadro 1: Despesas da União Condicionadas à quebra da Regra de Ouro

\begin{tabular}{|l|c|}
\hline \multicolumn{1}{|c|}{ DESPESAS CONDICIONADAS } & VALOR (R\$ bilhões) \\
\hline Benefícios Previdenciários do RGPS & 213,7 \\
\hline Pessoal e Encargos & 84,4 \\
\hline Bolsa Família & 0,5 \\
\hline Subsídios e Subvenções Econômicas & 4,8 \\
\hline Benefícios aos Servidores & 3,3 \\
\hline Demais & 36,9 \\
\hline \multicolumn{2}{|c|}{ TOTAL } \\
\hline
\end{tabular}

Fonte: Câmara dos Deputados, 2020b.

O governo Bolsonaro, ao propor a quebra da Regra de Ouro, admite que a arrecadação tributária prevista para o ano de 2020 não será suficiente para prover o total das despesas correntes e terá que emitir títulos da dívida no montante de $\mathrm{R} \$ 343,6$ bilhões para complementar a provisão de tais despesas. Tudo indica que o governo Bolsonaro vai utilizar essa circunstância para defender a aprovação da PEC 186/2019 e, assim, por meio de uma mudança constitucional, estabelecer dispositivos para reduzir despesas com pessoal, com a saúde e a educação. No lugar de propor uma reforma tributária que amplie a arrecadação, onere os mais ricos e beneficie os mais pobres, o governo atual propõe redução de despesas que irão resultar na restrição, ainda maior, do financiamento de políticas sociais.

\footnotetext{
19 Para Fattorelli (2013, p. 211), “[...] as despesas correntes correspondem a gastos de custeio e transferências que se consomem com a manutenção e funcionamento do Estado, as despesas de capital estão relacionadas a investimentos e transferências relacionadas a aquisição de bens patrimoniais ou financeiros que gerem retorno ou anulam despesa". As despesas com a amortização, juros e encargos da dívida pública são classificadas como despesas de capital.
} 
No Quadro 2, estão as despesas das universidades federais e da ciência e tecnologia da LOA/2020, condicionadas à quebra da Regra de Ouro, que dependem da emissão títulos da dívida pública. Caso o Congresso Nacional não aprove os créditos adicionais (emissão de títulos da dívida pública) solicitados pelo governo federal, o funcionamento das universidades e dos institutos e grupos de pesquisa poderá ser inviabilizado antes do final do ano de 2020.

Quadro 2: Percentual das despesas das universidades e da Ciência e Tecnologia condicionadas à quebra da Regra de Ouro

\begin{tabular}{|c|c|c|c|}
\hline & $\begin{array}{c}\text { Valor Total R\$ }[\mathrm{A}] \\
\text { (Recursos Ordinários + Recursos Condicionados) }\end{array}$ & $\begin{array}{c}\text { Valor condicionado à } \\
\text { quebra da Regra de Ouro } \\
\mathrm{R} \$[\mathrm{~B}]\end{array}$ & $\begin{array}{c}{[\mathbf{B}] /[\mathbf{A}]} \\
\mathbf{\%}\end{array}$ \\
\hline $\begin{array}{c}\text { Universidades } \\
\text { Federais } \\
\text { (incluindo Hospitais Universitários) }\end{array}$ & 55.654 .136 .651 & 8.591 .836 .779 & 15,44 \\
\hline Ciência e Tecnologia & 6.924 .733 .013 & 2.188 .201 .354 & 31,60 \\
\hline CAPES & 3.076 .539 .235 & 232.949 .333 & 7,57 \\
\hline CNPq & 1.371 .013 .446 & 61.081 .805 & 4,46 \\
\hline
\end{tabular}

Fonte: Câmara dos Deputados, 2020ª . Elaboração própria.

Detalham-se, na sequência, os recursos destinados pelo governo federal às universidades e à ciência e tecnologia no período de 2003 a 2020.

Tabela 1 - Recursos destinados às universidades federais (incluindo hospitais universitários) como percentual do PIB e das despesas da União (2003-2020). Valores (R \$ 1,00), a preços de janeiro de 2020 (IPCA

\begin{tabular}{|c|c|c|c|c|c|}
\hline \multirow{2}{*}{ ANO } & \multirow{2}{*}{$\begin{array}{c}\text { PIB } \\
\text { (A) }\end{array}$} & \multirow{2}{*}{$\begin{array}{c}\text { DESPESAS DA } \\
\text { UNIÃO } \\
\text { (B) }\end{array}$} & \multicolumn{3}{|c|}{ DESPESAS UNIVERSIDADES FEDERAIS } \\
\hline & & & $\mathbf{R} \$(C)$ & $\begin{array}{c}\% \\
\text { C/A }\end{array}$ & $\begin{array}{c}\% \\
\mathrm{C} / \mathrm{B}\end{array}$ \\
\hline 2003 & 4.211.710.012.370 & 2.148.712.205.705 & 21.827.738.454 & 0,52 & 1,02 \\
\hline 2004 & 4.502.553.704.644 & 2.088.681.722.276 & 24.724.203.442 & 0,55 & 1,18 \\
\hline 2005 & 4.671 .162 .968 .981 & 2.381 .846 .856 .298 & 23.877 .818 .414 & 0,51 & 1,00 \\
\hline 2006 & 4.977.007.947.861 & 2.445 .097 .507 .745 & 29.266 .265 .831 & 0,59 & 1,20 \\
\hline 2007 & 5.421 .592 .845 .553 & 2.438 .993 .437 .190 & 31.419 .580 .452 & 0,58 & 1,29 \\
\hline 2008 & 5.864 .933 .135 .813 & 2.374 .111 .613 .781 & 33.820 .323 .601 & 0,58 & 1,42 \\
\hline 2009 & 5.993 .004 .743 .155 & 2.546 .720 .783 .549 & 39.829 .498 .434 & 0,66 & 1,56 \\
\hline 2010 & 6.651 .831 .753 .070 & 2.576 .190 .454 .858 & 45.953 .004 .318 & 0,69 & 1,78 \\
\hline 2011 & 7.025 .274 .733 .140 & 2.691 .767 .024 .128 & 49.035 .008 .626 & 0,70 & 1,82 \\
\hline 2012 & 7.332 .783 .184 .800 & 2.801 .971 .783 .544 & 50.055 .888 .115 & 0,68 & 1,79 \\
\hline 2013 & 7.645 .594 .962 .190 & 2.768 .217 .060 .571 & 54.780 .051 .475 & 0,72 & 1,98 \\
\hline 2014 & 7.793 .784 .963 .450 & 3.113 .136 .660 .137 & 55.838 .692 .258 & 0,72 & 1,79 \\
\hline 2015 & 7.416 .488 .729 .650 & 2.850 .236 .012 .214 & 52.874 .373 .293 & 0,71 & 1,86 \\
\hline 2016 & 7.131 .611 .373 .120 & 2.945 .661 .858 .623 & 52.967 .041 .469 & 0,74 & 1,80 \\
\hline 2017 & 7.239.346.738.350 & 2.755.255.847.473 & 55.792 .502 .342 & 0,77 & 2,02 \\
\hline
\end{tabular}




\begin{tabular}{cccccc}
2018 & 7.307 .831 .314 .200 & 2.838 .886 .971 .424 & 55.830 .290 .539 & 0,76 & 1,97 \\
2019 & 7.321 .287 .099 .223 & 2.830 .870 .595 .151 & 55.975 .559 .228 & 0,76 & 1,98 \\
2020 & 7.613 .558 .523 .863 & 3.565 .520 .100 .068 & 55.654 .136 .651 & 0,73 & 1,56 \\
\hline$\Delta 2003-2019$ & $\mathbf{7 3 , 8 3 \%}$ & $\mathbf{3 1 , 7 5 \%}$ & $\mathbf{1 5 6 , 4 4 \%}$ & & \\
$\Delta 2003-2020$ & $\mathbf{8 0 , 7 7 \%}$ & $\mathbf{6 5 , 9 4 \%}$ & $\mathbf{1 5 4 , 9 7 \%}$ & & $\mathbf{1 , 6 2}$ \\
\multicolumn{2}{c}{$2003-2019(\%$ MÉDIO) } & & & $\mathbf{0 , 6 6}$ & \\
\hline
\end{tabular}

Fontes: Banco Central do Brasil, 2020. Senado Federal, 2019. Câmara dos Deputados, 2020. SIOP, 2020. Elaboração própria. Nota: os valores do PIB para os anos de 2019 e 2020 são projetados pelo Senado Federal. Instituição Fiscal Independente, 2019.

De 2003 a 2019 (orçamento executado), o governo federal destinou nada mais do que $1,62 \%$ do total de despesas orçamentárias da União para as universidades federais, incluindo os hospitais universitários. Isto representou, em média, o equivalente a 0,66\% do PIB nacional. No mesmo intervalo, vale a pena lembrar, as despesas com amortização, juros e encargos da dívida pública representaram nada menos do que $18,88 \%$ do orçamento da União e o equivalente a 7,89\% do PIB. Para 2020, a Lei Orçamentária previu inicialmente a destinação de R\$ 685,513 bilhões para amortização, juros e encargos da dívida. Esse montante representa $19,23 \%$ do orçamento da União (previsto) e o equivalente a 9\% do PIB (projetado). Os recursos previstos para o pagamento de amortização, juros e encargos da dívida em 2020 ( $\mathrm{R} \$ 685,513$ bilhões) representam 12 vezes mais os recursos previstos para as universidades federais, incluindo os hospitais universitários ( $\mathrm{R}$ \$ 55,654 bilhões).

No período de 2003 a 2019 (orçamento executado), ocorreu a elevação dos recursos destinados pelo governo federal às universidades federais (incluídos os hospitais universitários): de $\mathrm{R} \$ 21,828$ bilhões, em 2003, para R\$ 55,976 bilhões, em 2019, expressando um crescimento de 156,44\%, conforme expresso na Tabela 1.

Em 2003, os recursos para o setor representavam, proporcionalmente, 0,52\% do PIB e $1,02 \%$ do orçamento da União. Em 2019, passaram a representar 0,76\% e 1,98\%, respectivamente. Quando se analisa, porém, o orçamento das universidades federais, de acordo com o Grupo de Natureza da Despesa, observa-se que, nos últimos anos, os recursos destinados ao custeio (Outras Despesas Correntes) e ao investimento foram sensivelmente reduzidos.

No caso do orçamento previsto para as universidades para o ano de 2020, conforme já sinalizado, há o problema adicional da necessidade de o Congresso Nacional aprovar a emissão de títulos da dívida pública para a provisão do total de recursos previstos na LOA/2020. Mesmo com a autorização do Congresso Nacional, para a emissão de títulos da dívida para prover despesas correntes, o Orçamento Total das universidades federais para o 
ano de 2020 (R $\$ 55,654$ bilhões) é 0,58\% inferior ao orçamento executado em 2019 (R\$ 55,976 bilhões).

Como apresentado anteriormente, no Quadro 2, do total de recursos previstos pela LOA/2020 para as universidades e hospitais universitários ( $\mathrm{R}$ 55,654 bilhões) o equivalente a 15,44\% desse montante ( $\mathrm{R}$ \$ 8,592 bilhões) está condicionado à aprovação pelo Congresso Nacional da quebra da Regra de Ouro. ${ }^{20}$ No caso dos valores previstos para o pagamento de pessoal ( $\mathrm{R} \$ 46,409$ bilhões) 12,17\% ( $\mathrm{R} \$$ 5,649 bilhões) dependem da emissão de títulos da dívida pública. Quando se reporta ao custeio (ODC), a situação é ainda mais preocupante. Do total de recursos previstos para o custeio das universidades e hospitais universitários ( $\mathrm{R} \$$ 8,362 bilhões), 35,20\% dos recursos (R $\$ 2,943$ bilhões) dependem da emissão de títulos da dívida pública.

Na Tabela 2 estão expressas discriminadamente as despesas de acordo com o Grupo de Natureza da Despesa no período de 2003 a 2020.

Tabela 2 - Evolução das Despesas da União com as universidades federais (incluídos os hospitais universitários) por Grupo de Natureza da Despesa (GND): 2003-2020. Valores (R\$ $1,00)$ a preços de janeiro de 2020 (IPCA).

\begin{tabular}{|c|c|c|c|c|}
\hline ANO & PESSOAL & CUSTEIO & INVESTIMENTOS & TOTAL $^{1}$ \\
\hline 2003 & 18.817 .731 .020 & 2.406 .419 .011 & 225.902 .062 & 21.827 .738 .454 \\
\hline 2004 & 21.011 .110 .763 & 2.984 .837 .531 & 313.934 .183 & 24.724 .203 .442 \\
\hline 2005 & 19.887 .930 .430 & 3.167 .364 .854 & 428.912 .289 & 23.877 .818 .414 \\
\hline 2006 & 24.656 .749 .511 & 3.511 .129 .594 & 612.907 .746 & 29.266 .265 .831 \\
\hline 2007 & 25.654 .283 .500 & 4.093 .093 .831 & 1.161 .226 .589 & 31.419 .580 .452 \\
\hline 2008 & 27.656 .247 .748 & 4.449 .583 .936 & 1.172 .993 .609 & 33.820 .323 .601 \\
\hline 2009 & 31.119 .727 .728 & 5.396 .034 .453 & 2.693 .813 .334 & 39.829 .498 .434 \\
\hline 2010 & 35.378 .201 .948 & 6.995 .387 .052 & 2.873 .072 .680 & 45.953 .004 .318 \\
\hline 2011 & 36.822 .836 .216 & 7.566 .516 .281 & 3.923 .391 .801 & 49.035 .008 .626 \\
\hline 2012 & 37.240 .641 .857 & 8.180 .429 .356 & 3.870 .578 .933 & 50.055 .888 .115 \\
\hline 2013 & 40.392 .327 .713 & 9.888 .804 .484 & 3.676 .725 .381 & 54.780 .051 .475 \\
\hline 2014 & 42.806 .713 .492 & 9.247 .946 .807 & 2.933 .436 .580 & 55.838 .692 .258 \\
\hline 2015 & 43.231 .226 .914 & 7.931 .202 .805 & 864.037 .764 & 52.874 .373 .293 \\
\hline 2016 & 43.027 .168 .213 & 8.174 .818 .013 & 755.018 .987 & 52.967 .041 .469 \\
\hline 2017 & 46.737 .788 .750 & 7.598 .729 .143 & 548.093 .079 & 55.792 .502 .342 \\
\hline 2018 & 47.047 .356 .087 & 7.521 .178 .890 & 344.139 .145 & 55.830 .290 .539 \\
\hline 2019 & 48.644 .018 .978 & 7.123 .033 .264 & 182.274 .168 & 55.975 .559 .228 \\
\hline 2020 & 46.409 .394 .285 & 8.361 .978 .407 & 704.394 .095 & 55.654 .136 .651 \\
\hline $03-2019$ & $158,50 \%$ & $196,00 \%$ & $-19,31 \%$ & $156,44 \%$ \\
\hline
\end{tabular}

${ }^{20}$ A Regra de Ouro (Art. 167, inciso III da Constituição Federal) proíbe a utilização de recursos provenientes de dívida (emissão de títulos) para o pagamento de despesas correntes. Para descumprir a regra, o governo federal precisa obter autorização, por maioria absoluta, do Congresso Nacional. 
Fontes: Câmara dos Deputados, 2020. SIOP, 2020. Elaboração própria.

NOTA: o Total resulta da soma das despesas com Pessoal, Custeio, Investimentos, Juros, Amortização e Refinanciamento da Dívida, Inversões Financeiras e Reserva de Contingência.

Desde 2014 verificou-se grave restrição dos recursos destinados ao custeio (Outras Despesas Correntes) das universidades federais. Em 2013, as universidades (incluídos os hospitais universitários) receberam de $\mathrm{R} \$ 9,889$ bilhões para o custeio de suas atividades e em 2019 R \$ 7,123 bilhões, uma redução de 27,97\%. No caso dos recursos destinados aos investimentos, a situação é ainda pior. Em 2011, as universidades e os hospitais a elas vinculados receberam do governo federal R \$ 3,923 bilhões e em 2019 receberam apenas R\$ 182,274 milhões, uma redução de 95,29\%.

A crise de subfinanciamento das universidades federais se aprofunda, ainda mais, em 2020. Para este ano, a LOA prevê uma pequena elevação dos recursos de custeio e investimento. Os valores previstos, entretanto, estão abaixo dos recursos de custeio liquidados em 2013 e dos recursos para investimento liquidados em 2011. Em relação aos recursos globais, a LOA prevê uma redução de 0,59\% para 2020 (R\$ 55,654 bilhões), em comparação com o orçamento executado no ano anterior ( $\mathrm{R} \$ 55,976$ bilhões). No caso das despesas com pessoal, previu-se $\mathrm{R} \$ 46,409$ bilhões para o ano de 2020, uma redução de 4,59\% em relação ao orçamento executado em 2019 (48,644 bilhões).

Os números acima revelam que, já algum tempo, as universidades federais enfrentam sérias dificuldades para garantir o desenvolvimento de suas atividades. Os recursos que faltaram a elas, entretanto, foram canalizados para irrigar o crescimento dos grandes grupos financeiros/educacionais no Brasil, por meio do Fundo de Financiamento Estudantil (Fies) e do Programa Universidade Para Todos (Prouni).

Tabela 3 - Recursos destinados ao Fies e gastos tributários com o Prouni como percentual das despesas da União com as universidades federais - 2003-2020. Valores $(\mathrm{R} \$ 1,00)$ a preços de janeiro de 2020 (IPCA)

\begin{tabular}{ccccc}
\hline \multirow{2}{*}{ ANO } & $\begin{array}{c}\text { DESPESAS COM AS } \\
\text { UNIVERSIDADES FEDERAIS [A] }\end{array}$ & \multicolumn{2}{c}{ DESPESAS COM O FIES E O PROUNI } \\
\cline { 2 - 2 } 2003 & 21.827 .738 .454 & 1.740 .246 .800 & 7,97 \\
2004 & 24.724 .203 .442 & 1.605 .355 .082 & 6,49 \\
2005 & 23.877 .818 .414 & 1.923 .658 .410 & 8,06 \\
2006 & 29.266 .265 .831 & 2.333 .457 .306 & 7,97 \\
2007 & 31.419 .580 .452 & 2.628 .510 .665 & 8,37 \\
2008 & 33.820 .323 .601 & 3.023 .617 .191 & 8,94 \\
2009 & 39.829 .498 .434 & 3.448 .005 .140 & 8,66
\end{tabular}




\begin{tabular}{cccc}
2010 & 45.953 .004 .318 & 3.942 .240 .944 & 8,58 \\
2011 & 49.035 .008 .626 & 4.865 .709 .723 & 9,92 \\
2012 & 50.055 .888 .115 & 9.314 .358 .625 & 22,59 \\
2013 & 54.780 .051 .475 & 12.376 .367 .618 & 32,32 \\
2014 & 55.838 .692 .258 & 18.048 .278 .561 & 38,46 \\
2015 & 52.874 .373 .293 & 20.335 .991 .788 & 43,08 \\
2016 & 52.967 .041 .469 & 22.817 .596 .648 & 44,17 \\
2017 & 55.792 .502 .342 & 24.645 .435 .539 & 28,12 \\
2018 & 55.830 .290 .539 & 15.699 .453 .931 & 22,72 \\
2019 & 55.975 .559 .228 & 12.718 .788 .846 & 22,50 \\
2020 & 55.654 .136 .651 & 12.522 .918 .060 & $\mathbf{6 3 0 , 8 6}$ \\
\hline $\mathbf{2 0 0 3 - 2 0 1 9}$ (\%) & $\mathbf{1 5 6 , 4 4 \%}$ & $\mathbf{6 1 9 , 6 1}$ & $\mathbf{1 9 , 1 2}$ \\
\hline
\end{tabular}

Fontes: Câmara dos Deputados, 2020. SIOP, 2020. Ministério da Economia, 2019; 2020; 2020b. IPEA, 2008. Elaboração própria.

Do ponto de vista financeiro, no período de 2003 a 2019 (orçamento executado), as despesas da União com as universidades federais denotaram um crescimento de 156,44\%. Nesse mesmo período, os recursos públicos destinados pelo governo federal para financiar as instituições privadas de ensino superior, por meio do Fies e do Prouni, apresentaram um crescimento de 630,86\%: de R \$ 1,740 bilhão, em 2003, para R \$ 12,719 bilhões. Ao se tomar como referência o período de governo do Partido dos Trabalhadores, de 2003 a 2015, os recursos públicos destinados ao setor privado representaram o exponencial crescimento de 1.069\%: de R \$ 1,740 bilhão, em 2003, para R\$ 20,336 bilhões. Em 2017, o montante de recursos públicos destinados ao setor privado atingiu a cifra de $\mathrm{R} \$ 24,645$ bilhões, um crescimento de $1.316 \%$ em relação a 2003. Desde 2018, os recursos destinados ao Fies e Prouni são constantemente reduzidos. Comparando-se os recursos liquidados em 2017 e em 2019, observa-se redução de 48,39\%: de R \$ 24,645 bilhões para R \$ 12,718 bilhões.

Em 2003, os recursos públicos destinados ao setor privado representavam 7,97\% do orçamento das universidades federais (incluindo dos hospitais universitários). Em 2017, passaram a representar $44,17 \%$, enquanto em 2019 foram reduzidos para 22,50\%. O governo federal, especialmente o governo Dilma, aumentou significativamente os recursos públicos destinados ao financiamento da educação superior privada. Essa decisão política contribuiu para viabilizar o crescimento dos grandes grupos financeiros/educacionais, em especial os grupos de capital aberto, como a Kroton Educacional, Estácio Participações S/A, Ânima Educação e Ser Educacional (CHAVES; REIS; GUIMARÃES, 2018).

No que concerne ao financiamento da ciência e tecnologia, verificou-se nos últimos anos o agravamento do crônico subfinanciamento do setor no Brasil. A comparação dos 
gastos com a dívida pública e os investimentos em ciência e tecnologia revela que os recursos públicos foram canalizados prioritariamente para viabilizar a rentabilidade do capital rentista em prejuízo do fomento da ciência e tecnologia. Como visto anteriormente, as despesas com amortização, juros e encargos da dívida pública (excluído o refinanciamento), no período de 2003 a 2019, representaram, em média, nada menos do que $18,88 \%$ do orçamento da União, o equivalente a 7,89\% do PIB. Nesse mesmo período, o governo federal destinou para a ciência e tecnologia, $0,35 \%$ e $0,14 \%$, respectivamente, conforme discriminado na Tabela 4.

No período de 2003 a 2019 (orçamento executado), as despesas da União com a função ciência e tecnologia foram ampliadas: de $\mathrm{R} \$ 4,886$ bilhões, em 2003, para R \$ 6,721 bilhões, em 2019, um crescimento de 37,55\%. Em 2003, os recursos para o setor representavam, proporcionalmente, $0,12 \%$ do PIB e $0,23 \%$ do orçamento da União. Em 2019, passaram a representar $0,09 \%$ e $0,24 \%$, respectivamente.

Tabela 4 - Recursos destinados à função ciência e tecnologia como percentual do PIB e das despesas da União (2003-2020). Valores (R\$ 1,00) a preços de janeiro de 2020 (IPCA)

\begin{tabular}{|c|c|c|c|c|c|}
\hline \multirow[b]{2}{*}{ ANO } & \multirow{2}{*}{$\begin{array}{l}\text { PIB } \\
{[A]}\end{array}$} & \multirow{2}{*}{$\begin{array}{l}\text { DESPESAS DA UNIÃO } \\
{[\text { [B] }}\end{array}$} & \multicolumn{3}{|c|}{ DESPESAS CIÊNCIA E TECNOLOGIA } \\
\hline & & & $\mathbf{R} \$[C]$ & $\begin{array}{c}\% \\
{[\mathrm{C}] /[\mathrm{A}]}\end{array}$ & $\begin{array}{c}\% \\
{[C] /[B]}\end{array}$ \\
\hline 2003 & 4.211.710.012.370 & 2.148.712.205.705 & 4.886.494.358 & 0,12 & 0,23 \\
\hline 2004 & 4.502 .553 .704 .644 & 2.088.681.722.276 & 5.995 .920 .697 & 0,13 & 0,29 \\
\hline 2005 & 4.671.162.968.981 & 2.381.846.856.298 & 7.046.741.289 & 0,15 & 0,30 \\
\hline 2006 & 4.977.007.947.861 & 2.445 .097 .507 .745 & 7.886.568.927 & 0,16 & 0,32 \\
\hline 2007 & 5.421 .592 .845 .553 & 2.438.993.437.190 & 8.625 .344 .536 & 0,16 & 0,35 \\
\hline 2008 & 5.864 .933 .135 .813 & 2.374.111.613.781 & 9.853 .622 .592 & 0,17 & 0,42 \\
\hline 2009 & 5.993 .004 .743 .155 & 2.546.720.783.549 & 11.130 .028 .316 & 0,19 & 0,44 \\
\hline 2010 & 6.651 .831 .753 .070 & 2.576.190.454.858 & 12.915 .210 .029 & 0,19 & 0,50 \\
\hline 2011 & 7.025 .274 .733 .140 & 2.691.767.024.128 & 11.237 .306 .521 & 0,16 & 0,42 \\
\hline 2012 & 7.332.783.184.800 & 2.801.971.783.544 & 11.895 .336 .725 & 0,16 & 0,42 \\
\hline 2013 & 7.645.594.962.190 & 2.768 .217 .060 .571 & 15.401 .036 .956 & 0,20 & 0,56 \\
\hline 2014 & 7.793.784.963.450 & 3.113 .136 .660 .137 & 11.243 .954 .025 & 0,14 & 0,36 \\
\hline 2015 & 7.416.488.729.650 & 2.850 .236 .012 .214 & 8.109 .154 .363 & 0,11 & 0,28 \\
\hline 2016 & 7.131 .611 .373 .120 & 2.945 .661 .858 .623 & 7.077.194.078 & $0,10 \%$ & 0,24 \\
\hline 2017 & 7.239.346.738.350 & 2.755 .255 .847 .473 & 6.859 .565 .909 & 0,09 & 0,25 \\
\hline 2018 & 7.307.831.314.200 & 2.838 .886 .971 .424 & 6.938 .330 .836 & 0,09 & 0,24 \\
\hline 2019 & 7.321.287.099.223 & 2.830 .870 .595 .151 & 6.721 .301 .401 & 0,09 & 0,24 \\
\hline 2020 & 7.613.558.523.863 & 3.565 .520 .100 .068 & 6.964 .624 .580 & 0,09 & 0,20 \\
\hline$\Delta$ 2003-2019 & $73,83 \%$ & $31,75 \%$ & $\mathbf{3 7 , 5 5 \%}$ & & \\
\hline$\Delta 2003-2020$ & $80,77 \%$ & $65,94 \%$ & $42,53 \%$ & & \\
\hline $2003-2$ & \% MÉDIO) & & & 0,14 & $\mathbf{0 , 3 4}$ \\
\hline
\end{tabular}

Fontes: Banco Central do Brasil, 2020. Senado Federal, 2019. Câmara dos Deputados, 2020. SIOP, 2020. Elaboração própria. 
Desde 2014, se verificou drástica redução orçamentária. Assim, enquanto em 2013 foram destinados para a ciência e tecnologia R\$ 15,401 bilhões, em 2019 os valores liquidados não ultrapassaram $\mathrm{R} \$ 6,721$ bilhões, uma redução de 56,36\%. A restrição orçamentária iniciada no governo Dilma Rousseff e aprofundada nos governos pós-golpe de Michel Temer e de Jair Bolsonaro resultam da política de ajuste fiscal e contenção das despesas com políticas sociais que marca todo esse período. Por outro lado, o governo de Michel Temer e, especialmente, o de Jair Bolsonaro, compreendem que as universidades e instituições de pesquisa constituem um bastião do pensamento crítico e de oposição ao projeto ultraliberal em curso. Esta compreensão tem orientado a efetivação de cortes orçamentários draconianos que poderão inviabilizar a sobrevivência de tais instituições.

No orçamento previsto para o ano de 2020, para agravar a situação, parte dos recursos destinados para a ciência e tecnologia depende da quebra da Regra de Ouro, da emissão de títulos da dívida pública, conforme apontado anteriormente no Quadro 2. Do total de recursos previstos na LOA/2020 ( $\mathrm{R}$ \% 6,925 bilhões) 31,60\% ( $\mathrm{R}$ 2,188 bilhões) estão condicionados à quebra da Regra de Ouro.

A crise de subfinanciamento da educação e da ciência e tecnologia espraia-se para os órgãos que recebem recursos dessas áreas: a Coordenação de Aperfeiçoamento de Pessoal de Nível Superior (CAPES) e o Conselho Nacional de Desenvolvimento Científico e Tecnológico (CNPq).

Relativamente ao Conselho Nacional de Desenvolvimento Científico e Tecnológico (CNPq), a crise de subfinanciamento chegou ao ponto de as verbas destinadas ao órgão pela União em 2019 (R\$ 1,442 bilhão) estarem abaixo do valor liquidado em 2003 (R\$ 1,664 bilhão), uma redução de 13,36\%. A partir de 2014, verificou-se um decréscimo constante dos recursos destinados ao CNPq: em 2013, foram destinados R \$ 3,029 bilhões e em 2019 R \$ 1,442 bilhão, o que significa redução de 52,39\% em seis anos, conforme apresentado na Tabela 5.

Tabela 5- Recursos destinados ao Conselho Nacional de Desenvolvimento Científico e Tecnológico (CNPq) como percentual do PIB e das despesas da União (2003-2020). Valores (R\$1,00) a preços de janeiro de 2020 (IPCA)

\begin{tabular}{|c|c|c|c|c|c|}
\hline \multirow{2}{*}{ ANO } & \multirow{2}{*}{$\begin{array}{l}\text { PIB } \\
{[\mathbf{A}]}\end{array}$} & \multirow{2}{*}{$\begin{array}{c}\text { DESPESAS DA UNIÃO } \\
{[\mathrm{B}]}\end{array}$} & \multicolumn{3}{|c|}{ DESPESAS CNPq [C] } \\
\hline & & & $\mathbf{R} \$[\mathbf{C}]$ & $\begin{array}{c}\% \\
{[\mathrm{C}] /[\mathrm{A}]}\end{array}$ & $\begin{array}{c}\% \\
{[\mathrm{C}] /[\mathrm{B}]}\end{array}$ \\
\hline 2003 & 4.211.710.012.370 & 2.148.712.205.705 & 1.664 .380 .732 & 0,04 & 0,08 \\
\hline 2004 & 4.502 .553 .704 .644 & 2.088.681.722.276 & 1.707 .464 .255 & 0,04 & 0,08 \\
\hline 2005 & 4.671.162.968.981 & 2.381.846.856.298 & 1.721 .817 .973 & 0,04 & 0,07 \\
\hline 2006 & 4.977.007.947.861 & 2.445.097.507.745 & 1.839.176.600 & 0,04 & 0,08 \\
\hline
\end{tabular}




\begin{tabular}{|c|c|c|c|c|c|}
\hline 2007 & 5.421 .592 .845 .553 & 2.438.993.437.190 & 1.797.259.376 & 0,03 & 0,07 \\
\hline 2008 & 5.864 .933 .135 .813 & 2.374.111.613.781 & 1.563.157.927 & 0,03 & 0,07 \\
\hline 2009 & 5.993 .004 .743 .155 & 2.546.720.783.549 & 1.923 .595 .538 & 0,03 & 0,08 \\
\hline 2010 & 6.651 .831 .753 .070 & 2.576.190.454.858 & 2.005 .856 .353 & 0,03 & 0,08 \\
\hline 2011 & 7.025.274.733.140 & 2.691.767.024.128 & 1.988 .372 .331 & 0,03 & 0,07 \\
\hline 2012 & 7.332 .783 .184 .800 & 2.801 .971 .783 .544 & 2.419 .270 .463 & 0,03 & 0,09 \\
\hline 2013 & 7.645 .594 .962 .190 & 2.768.217.060.571 & 3.028 .625 .430 & 0,04 & 0,11 \\
\hline 2014 & 7.793.784.963.450 & 3.113 .136 .660 .137 & 2.870 .583 .166 & 0,04 & 0,09 \\
\hline 2015 & 7.416.488.729.650 & 2.850 .236 .012 .214 & 1.984.046.246 & 0,03 & 0,07 \\
\hline 2016 & 7.131.611.373.120 & 2.945 .661 .858 .623 & 1.473 .093 .881 & 0,02 & 0,05 \\
\hline 2017 & 7.239.346.738.350 & 2.755 .255 .847 .473 & 1.425 .630 .137 & 0,02 & 0,05 \\
\hline 2018 & 7.307.831.314.200 & 2.838.886.971.424 & 1.342 .234 .706 & 0,02 & 0,05 \\
\hline 2019 & 7.321.287.099.223 & 2.830 .870 .595 .151 & 1.442 .063 .007 & 0,02 & 0,05 \\
\hline 2020 & 7.613.558.523.863 & 3.565 .520 .100 .068 & 1.371 .013 .446 & 0,02 & 0,04 \\
\hline$\Delta 2003-2019$ & $73,83 \%$ & $31,75 \%$ & $-13,36 \%$ & & \\
\hline$\Delta 2003-2020$ & $80,77 \%$ & $65,94 \%$ & $-17,63 \%$ & & \\
\hline 2003-2019 (\% MÉD & & & & $\mathbf{0 , 0 3}$ & $\mathbf{0 , 0 7}$ \\
\hline
\end{tabular}

Fontes: Banco Central do Brasil, 2020. Senado Federal, 2019. Câmara dos Deputados, 2020. SIOP, 2020. Elaboração própria.

O total de recursos previstos na LOA/2020 para o CNPq (R\$1,371 bilhão) é 4,93\% inferior ao orçamento executado em 2019 (R\$ 1,442 bilhão). Além disso, do quantitativo de recursos previstos na LOA/2020 ( $\mathrm{R} \$ 1,371$ bilhão) 4,46\% ( $\mathrm{R}$ \$ 61,082 milhões) estão condicionados à emissão de títulos da dívida pública. Caso não haja a emissão de títulos da dívida, o orçamento do CNPq, previsto para o ano de 2020, será de R $\$ 1,310$ bilhão, 9,16\% menor que o orçamento executado em 2019 (R\$ 1,442 bilhão).

A Coordenação de Aperfeiçoamento de Pessoal de Nível Superior (CAPES), também, é alvo de graves restrições orçamentárias, especialmente a partir de 2016, conforme a Tabela 6.

Tabela 6 - Recursos destinados à Coordenação de Aperfeiçoamento de Pessoal de Nível Superior (CAPES) como percentual do PIB e das despesas da União (2003-2020). Valores (R\$1,00) a preços de janeiro de 2020 (IPCA)

\begin{tabular}{|c|c|c|c|c|c|}
\hline \multirow[t]{2}{*}{ ANO } & \multirow[t]{2}{*}{$\begin{array}{l}\text { PIB } \\
{[A]}\end{array}$} & \multirow[t]{2}{*}{$\begin{array}{c}\text { DESPESAS DA UNIÃO } \\
{[\mathrm{B}]}\end{array}$} & \multicolumn{3}{|c|}{ DESPESAS CAPES } \\
\hline & & & $\begin{array}{l}\mathrm{R} \$ \\
{[\mathrm{C}]}\end{array}$ & $\begin{array}{c}\% \\
{[\mathrm{C}] /[\mathrm{A}]}\end{array}$ & $\begin{array}{c}\% \\
{[\mathrm{C}] /[\mathrm{B}]}\end{array}$ \\
\hline 2003 & 4.211 .710 .012 .370 & 2.148.712.205.705 & 1.313 .336 .415 & 0,03 & 0,06 \\
\hline 2004 & 4.502 .553 .704 .644 & 2.088.681.722.276 & 1.302 .244 .376 & 0,03 & 0,06 \\
\hline 2005 & 4.671.162.968.981 & 2.381.846.856.298 & 1.415 .102 .581 & 0,03 & 0,06 \\
\hline 2006 & 4.977.007.947.861 & 2.445.097.507.745 & 1.517 .691 .534 & 0,03 & 0,06 \\
\hline 2007 & 5.421 .592 .845 .553 & 2.438.993.437.190 & 1.556 .671 .091 & 0,03 & 0,06 \\
\hline 2008 & 5.864 .933 .135 .813 & 2.374.111.613.781 & 2.377 .436 .565 & 0,04 & 0,10 \\
\hline
\end{tabular}




\begin{tabular}{|c|c|c|c|c|c|}
\hline 2009 & 5.993 .004 .743 .155 & 2.546.720.783.549 & 2.917.822.124 & 0,05 & 0,11 \\
\hline 2010 & 6.651 .831 .753 .070 & 2.576.190.454.858 & 3.421 .868 .111 & 0,05 & 0,13 \\
\hline 2011 & 7.025.274.733.140 & 2.691.767.024.128 & 4.414.179.299 & 0,06 & 0,16 \\
\hline 2012 & 7.332 .783 .184 .800 & 2.801.971.783.544 & 5.385 .412 .022 & 0,07 & 0,19 \\
\hline 2013 & 7.645.594.962.190 & 2.768.217.060.571 & 6.928 .511 .116 & 0,09 & 0,25 \\
\hline 2014 & 7.793.784.963.450 & 3.113 .136 .660 .137 & 7.522.208.420 & 0,10 & 0,24 \\
\hline 2015 & 7.416.488.729.650 & 2.850 .236 .012 .214 & 9.469 .040 .451 & 0,13 & 0,33 \\
\hline 2016 & 7.131.611.373.120 & 2.945 .661 .858 .623 & 5.760 .296 .856 & 0,08 & 0,20 \\
\hline 2017 & 7.239.346.738.350 & 2.755 .255 .847 .473 & 4.331.699.544 & 0,06 & 0,16 \\
\hline 2018 & 7.307.831.314.200 & 2.838 .886 .971 .424 & 3.548 .619 .725 & 0,05 & 0,13 \\
\hline 2019 & 7.321.287.099.223 & 2.830 .870 .595 .151 & 3.910 .995 .042 & 0,05 & 0,14 \\
\hline 2020 & 7.613.558.523.863 & 3.565 .520 .100 .068 & 3.076 .539 .235 & 0,04 & 0,09 \\
\hline$\Delta 2003-2019$ & $\mathbf{7 3 , 8 3 \%}$ & $31,75 \%$ & $197,79 \%$ & & \\
\hline$\Delta 2003-2020$ & $80,77 \%$ & $65,94 \%$ & $134,25 \%$ & & \\
\hline 2003-2019 (\% MÉDIO) & & & & 0,06 & 0,14 \\
\hline
\end{tabular}

Fontes: Banco Central do Brasil, 2020. Senado Federal, 2019. Câmara dos Deputados, 2020. SIOP, 2020. Elaboração própria.

Os recursos destinados pela União à CAPES foram ampliados de R\$ 1,313 bilhão, em 2003, para R\$ 3,911 bilhões, em 2019, o que representa um crescimento de 197,79\%. A partir de 2016, todavia, se verificou grave decréscimo: em 2015, a União destinou R \$ 9,469 bilhões para a CAPES e, em 2019, R\$ 3,911 bilhões, expressando uma redução da ordem de $58,70 \%$ em quatro anos.

O montante de recursos previsto na LOA/2020 para a CAPES (R \$ 3,077 bilhões) é 21,34\% inferior ao orçamento executado em 2019 (R \$ 3,911 bilhões). Do total de recursos previstos para 2020 (R\$ 3,077 bilhões), 7,57\% (R \$ 232,949 milhões) estão condicionados à emissão de títulos da dívida pública. Caso não haja a emissão de títulos da dívida, o orçamento da CAPES, previsto para o ano de 2020, será de R \$2,844 bilhões, 27,28\% inferior ao executado em 2019.

\section{Considerações finais}

Apresentamos ao longo do texto a hipótese de que há inequívoca continuidade do padrão de acumulação de capital instaurado no País a partir dos anos 1990. As configurações políticas e ideológicas exigidas e assumidas pelo referido padrão oscilaram entre o conservadorismo orientado pelo Consenso de Washington - sob os governos de Collor de Melo, Itamar Franco e Fernando Henrique Cardoso - e o neodesenvolvimentismo, que opera inflexões na relação entre Estado e mercado, com aumento do protagonismo do primeiro no 
financiamento dos investimentos privados e na promoção de políticas públicas. As modulações operadas em nada feriram a estrutura de propriedade e de poder incrustada na sociedade brasileira, razão por que a autocracia burguesa se repôs agora de modo avassalador. Quanto ao padrão de acumulação, o resultado da "onda progressista" no Brasil foi o aprofundamento do neoextrativismo e da reprimarização, a concentração de capital e riqueza e o fortalecimento do rentismo baseado, em parte, no sistema tributário e da dívida pública.

No curso desta fase - a segunda do neoliberalismo brasileiro - e em decorrência da política de colaboração de classes que a sustentou, as empresas que monopolizam o mercado do ensino superior gozaram de ampla expansão, tendo no fundo público a principal fonte de financiamento. Os dados sobre o Fies e o ProUni provam isto. Houve, por outro lado, uma expansão das universidades e dos institutos federais que exigiu incremento de verbas para o setor. O mesmo se verificou em relação ao complexo público de ciência e tecnologia.

Com o esgotamento dos chamados governos progressistas e a assunção ao governo central de forças políticas retrógradas e de extrema direita, tem-se o início da terceira fase do neoliberalismo brasileiro aqui denominada de ultraliberalismo. Nesta, a agenda de ajustes iniciada por Dilma Rousseff, em 2015, foi expandida e aprofundada e já conseguiu implementar contrarreformas estruturantes, que rebaixam as rendas do trabalho e os gastos estatais com área social. As influências - negativas e regressivas - nas universidades federais e no complexo público de C\&T já causaram verdadeiros desastres. O prognóstico para o próximo ano é desalentador.

A pesquisa demonstrou que a crise orçamentária do setor aprofundou a partir de 2014 e, desde então, somente se agrava, juntando-se com os limites estruturais advindos do próprio padrão de acumulação que tem na dívida pública e no sistema tributário regressivo duas de suas bases. Estes dois elementos constituem robustos impeditivos para o investimento nas políticas públicas em geral e, em particular, no ensino superior e no complexo público de C\&T. Junte-se a estes elementos de ordem estrutural, a direção política e ideológica ultraliberal e conservadora, responsável, não apenas, pelos cortes orçamentários, mas também por virulentos ataques morais contra as universidades públicas, pesquisadores e servidores públicos.

Assim, a crise de financiamento das universidades e de outras instituições públicas vinculadas à produção de C\&T integra o projeto empunhado pela burguesia e pelo Estado brasileiro por ocasião do esgotamento do ciclo comandado pela política de colaboração de classe. A crise integra um projeto econômico, político e ideológico que se apoia em cinco vetores: privatização de todos os ativos estatais; desnacionalização de setores estratégicos; 
rebaixamento do padrão de uso da força de trabalho; estreitamento das margens orçamentárias para políticas públicas e liberalização dos gastos com a dívida pública; criminalização da esquerda e dos movimentos sociais mais expressivos. Esses vetores se retroalimentam, se determinam reflexivamente, formando as bases para importantes inflexões no neoliberalismo brasileiro e o precipitando para uma nova fase - aqui chamada de ultraliberalismo.

Eis por que o enfrentamento consequente da crise das universidades federais e da ciência e tecnologia no Brasil inscreve-se nas lutas mais gerais da sociedade contra a agenda regressiva em seu conjunto. Não é, pois, um aspecto somente orçamentário.

\section{REFERÊNCIAS}

ANDERSON, P. A crise no Brasil. Traduzido para o Português por Fernando Puresa. In: London Review of Books. V. 38, n. 8, 21 de abril de 2016.

BANCO CENTRAL DO BRASIL. Estatísticas. Séries Temporais. Atividade Econômica. Setor Real. Contas Nacionais. Produto Interno Bruto. Pib em R\$ correntes: 2003-2018. Disponível em: <https://www3.bcb.gov.br/sgspub/localizarseries/localizarSeries.do?method= prepararTela LocalizarSeries>. Acesso em 20 jan. 2020a.

BANCO CENTRAL DO BRASIL. Estatísticas. Notas econômico-financeiras à imprensa. Histórico de Estatísticas: Política Fiscal (Dívida Interna); Setor Externo (Dívida Externa). Disponível em: 〈https://www.bcb.gov.br/ estatisticas/historicoestatisticas > . Acesso em 20 jan. 2020b.

BANCO CENTRAL DO BRASIL. Estatísticas. Notas econômico-financeiras à imprensa. Histórico de Estatísticas: Política Fiscal (Dívida Interna); Setor Externo (Dívida Externa). Disponível em: 〈https://www.bcb.gov.br/ estatisticas/historicoestatisticas〉 . Acesso em 20 mar. 2019b.

BRASIL. Constituição (1988). Constituição: República Federativa do Brasil. Brasília, DF. Disponível em: 〈https://www.planalto.gov.br/ccivil_03/constituicao/constituicao.htm>. Acesso em 15 jan.2020.

BRETAS, Tatiana. Dívida pública: uma varinha de condão sobre os recursos do fundo público. In: SALVADOR, Evilásio et al. (Org.) Financeirização, fundo público e política social. São Paulo: Cortez, 2012. p. 93-120.

CÂMARA DOS DEPUTADOS. Orçamento da União: Execução Orçamentária e Financeira da União (2003-2018). Disponível em: 〈https://www2.camara.leg.br/orcamento-da-uniao〉. Acesso em 27 jan. 2020a.

CÂMARA DOS DEPUTADOS. Consultoria de Orçamento e fiscalização Financeira. Raio X Orçamento 2020: autógrafo. 2020b. Disponível em: 
<https://www2.camara.leg.br/orcamento-da-uniao/raio-X-do-orcamento-previdencia/raio-Xdo-orcamento-2020-autografo-vf> Acesso em 8 fev.2020.

CHAVES, V. L. J.; REIS, L. F.; GUIMARÃES, A. R. Dívida pública e financiamento da educação superior no Brasil. Acta Scientiarum. Education, v. 40, n. 1, p. 1-12. 2018.

CHILE aprova reforma tributária que aumenta impostos para os mais ricos e beneficia idosos. O Globo, Rio de Janeiro, 31 de jan. 2020. Disponível em:

$<$ https://oglobo.globo.com/mundo/ chile-aprova-reforma-tributaria-que-aumenta-impostospara-os-mais-ricos-beneficia-idosos-24219086>. Acesso em 5 fev. 2020.

FATTORELLI, M. L. Auditoria cidadã da dívida pública: experiências e métodos. Brasília: Inove, 2013.

GOMBATA, Marsílea. Chile propõe subir impostos por mais gasto social. Valor Econômico, São Paulo, 19 dez. 2019. Disponível em: <https://valor.globo.com/mundo/ noticia/2019/12/ 19/chile-propoe-subir-impostos-por-mais-gasto-social.ghtml >. Acesso em 5 fev. 2020.

IPEA (Instituto de Pesquisa Econômica Aplicada). 2008. Boletim de Políticas Sociais. Acompanhamento e Análise, 16, Brasília, DF: IPEA. Disponível em:

$<$ http://www.ipea.gov.br/portal/index.php?option=com_content\&view=article\&id=5779\&Ite mid=9>. Acesso em 12 fev. 2020.

LIMA, K. Contra-reforma na educação superior: de FHC a Lula. São Paulo: Xamã, 2007.

LIMA, K.; PEREIRA, L. D. Contra-reforma na educação superior brasileira: impactos na formação profissional em Serviço Social. In: Sociedade em Debate, 15(1): 31-50, Pelotas: jan.-jun./2009.

MASCARO, A. L. Crise e golpe. São Paulo: Boitempo, 2018.

MINISTÉRIO DA ECONOMIA. Receita Federal. Centro de Estudos Tributários e Aduaneiros. Demonstrativo dos Gastos Tributários Bases Efetivas: 2011-2019. Disponível em: <https://receita.economia.gov.br/dados/receitadata/renuncia-fiscal/ demonstrativos-dosgastos-tributarios/dgt-bases-efetivas $>$. Acesso em 15 jan. 2020.

MINISTÉRIO DA ECONOMIA. Receita Federal. Centro de Estudos Tributários e Aduaneiros. Demonstrativo dos Gastos Governamentais Indiretos de Natureza Tributária (Gastos Tributários). PLOA 2020. Ago. 2019. Disponível em:

$<$ http://receita.economia.gov.br/dados/receitadata/renuncia-fiscal/previsoes-ploa $>$ Acesso em 12 dez. 2019.

OLIVEIRA, F. de. Os direitos do antivalor - a economia política da hegemonia imperfeita. Petrópolis/RJ: Vozes, 1998.

PAULANI, L. Brasil delivery. São Paulo: Boitempo, 2008.

PMDB (Partido do Movimento Democrático Brasileiro). Uma ponte para o Futuro. Fundação Ulysses Guimarães. Brasília, 2015. 
REIS, L. F. e MACÁRIO, E. Dívida pública, sistema tributário e financiamento de C\&T no Brasil (2003-2017). IN: MACÁRIO, E. et alii (org.). Dimensões da crise brasileira dependência, trabalho e fundo público. Fortaleza: EdUece; Bauru: Canal 6, 2018. E-book disponível para free download em http://www.uece.br/eduece/dmdocuments/Dimenso \%CC\%83es\%20da\%20Crise\%20Brasileira\%20e_Book.pdf.

SALVADOR, E. Fundo público e seguridade social no Brasil. São Paulo: Cortez, 2010

SAMPAIO JR., P. de A. Desenvolvimentismo e neodesenvolvimentismo: tragédia e farsa. In: Revista Serviço Social \& Sociedade, número 112, São Paulo: 2012. Disponível em: http://www.scielo.br/pdf/sssoc/n112/04.pdf. Acesso dia 24/12/2019.

SANTOS, F. L. B. dos. Uma história da onda progressista sul-americana (1998-2016). São Paulo: Elefante, 2018.

SECRETARIA DA RECEITA FEDERAL. Carga Tributária no Brasil - 2016 (Análise por tributo e base de incidência). 2017. Disponível em: <http://receita.economia.gov.br/dados/ receitadata/estudos-e-tributarios-e-aduaneiros/estudos-e-estatisticas/carga-tributaria-nobrasil/carga-tributaria-2016.pdf> Acesso em 7 set. 2018.

SENADO FEDERAL. Instituição Fiscal Independente. Relatório de Acompanhamento Fiscal. Junho de 2018. Disponível em: <https://www2.senado.leg.br/bdsf/bitstream/ handle/id/542807/RAF17_JUN2018.pdf>. Acesso em 11 out. 2019.

SENADO FEDERAL. Instituição Fiscal Independente. Projeções IFI. 18 nov. 2019.

Disponível em: <https://www12.senado. leg.br/ifi/dados/arquivos/projecoes-ifi/view>. Acesso em 5 fev. 2020.

SICSÚ, J. Dez anos que abalaram o Brasil: e o futuro? São Paulo: Geração Editorial, 2013.

SILVA, R. B. da. O marco legal da ciência, tecnologia e inovação: a comunidade de pesquisa e a apropriação privada dos recursos públicos. Disponível em:

http://doi.editoracubo.com.br/10.4322/ifsr. 2016.003. Acesso em 26/12/2019.

SINGER, A. O Lulismo em Crise: um quebra-cabeça do período Dilma (2011-2016). São Paulo: Companhia das Letras, 2018.

SINGER, A. Os sentidos do Lulismo: reforma gradual e pacto conservador. São Paulo: Companhia das Letras, 2012.

SIOP. Sistema Integrado de Orçamento e Planejamento. Painel do Orçamento Federal. Disponível em: <https://www.siop.planejamento.gov.br/modulo/login/index.html\#/>. Acesso em 8 fev. 2020.

SVAMPA, M. Del cambio de época al fin de ciclo - gobiernos progresistas, extractivismo y movimientos sociales en América Latina. Buenos Aires: Edhesa, 2017. 
VOTAÇÃO da PEC Emergencial fica para 2020. Agência Senado. 10 dez. 2019. Disponível em: <https://www12.senado.leg.br/noticias/materias/2019/12/10/votacao-da-pec-emergencialfica-para-2020>. Acesso em 15 jan. 2020.

\section{SOBRE OS AUTORES:}

\section{Luiz Fernando Reis}

É Doutor em Políticas Públicas e Formação Humana pela Universidade do Estado do Rio de Janeiro (UERJ). Professor do curso de Enfermagem da Universidade Estadual do Oeste do Paraná (Unioeste/Cascavel). Membro do Grupo de Pesquisa em Políticas Educacionais e Sociais (Geppes Unioeste/Cnpq) e da Rede de Pesquisa Universitas/BR. E-mail: reisluizfernando@gmail.com

iD http://orcid.org/0000-0003-2982-1163

\section{Epitácio Macário}

É Doutor em Educação pela Universidade Federal do Ceará (UFC). Professor de Economia Política na Universidade Estadual do Ceará (UECE). Docente do Mestrado Acadêmico em Serviço Social, Trabalho e Questão Social (MASS) da Universidade Estadual do Ceará. Líder do Grupo de Pesquisa "Trabalho, sociabilidade e lutas sociais" cadastrado no diretório de grupos de pesquisa do CNPq. Membro do Centro de Estudos do Trabalho e Ontologia do Ser Social (CETROS). E-mail: epitacio.macario@uece.br

(iD http://orcid.org/0000-0001-6234-9732 